\title{
Projekt CZ.07.1.02/0.0/0.0/16_040/0000380 „Analýza adaptačních opatření ke zmírnění dopadů změny klimatu a urbanizace na vodní režim v oblasti vnější Prahy“"
}

\author{
ANNA HRABÁNKOVÁ, JOSEF VOJTĚCH DATEL, TOMÁŠ HRDINKA
}

Rádi bychom vás seznámili se základními údaji o projektu, který byl řešen v období 2018-2020 v rámci operačního programu Praha - pól růstu. Za tímto textem jsou pak uvedeny články zabývající se již specifickými tématy, jež byla $\checkmark$ rámci projektu řešena.

S územním rozvojem hlavního města Prahy dochází ke změnám prírodních podmínek na jejím území. S tím, jak jsou postupně zastavovány dosud volné plochy či zemědělská půda, nastávají změny v hydrologických poměrech jednotlivých toků i podzemních vod. Dochází ke zmenšování príirozených infiltračních ploch, k jinému režimu zasakování vlivem umělých zasakovacích opatření a k řízeným i neřízeným změnám odtokových poměrů. Lze rozlišit dvě situace, které mohou nastat. $V$ převážně zastavěných částech hlavního města jsou hydrogeologické poměry podzemních vod významně ovlivněny odkanalizováním území, a proto zde významnou roli hraje odtok povrchových vod. V méně zastavěných oblastech při vnějších okrajích hlavního města jsou víceméně zachovány původní přírodní odtokové poměry a významnou roli tu hraje nejen povrchový odtok, ale i infiltrace do podzemních vod a podzemní odtok.

Projekt si kladl za cíl posoudit dlouhodobý vliv postupující urbanizace na vodní režim v okrajových částech Prahy, a to v úzké vazbě na probíhající klimatické změny a jejich očekávané dopady v budoucnu. Cílem projektu bylo posoudit účinnost stávajících navržených a již realizovaných adaptačních opatření, prípadně navržení dalších doplňujících opatření, zavést poloprovoz systému umožňujícího hodnocení okamžitých srážkoodtokových poměrů na malých tocích a vytvoření užitného vzoru - typového projektu takového opatření. Těžiště prací bylo směřováno na území povodí horních částí místních malých toků pritékajících z území Středočeského kraje nebo pramenících v okrajových, málo urbanizovaných částech území Prahy, které často nebyly $\checkmark$ centru pozornosti doposud provedených prací, průzkumů a studií vodních poměrů. Projekt zahrnoval také stanovení dlouhodobého časového vývoje a trendů ve změnách hydrologických poměrů (ve formě aplikace hydrologického bilančního modelu a podrobných analýz časových řad hydrologicko-klimatologických parametrů - srážky, teploty, výpar, infiltrace, povrchový a podzemní odtok) a dále i analýzu charakteru a výskytu specifických hydrologických extrémů (sucho, bleskové povodně), která doplňuje a kompletuje informace, jež jsou dostupné ve Studii odtokových poměrů (mapy rozlivu - záplavová území). Zjištěné změny, trendy a časový vývoj hydrologických charakteristik byly vyhodnoceny jednak z pohledu dopadů změn klimatu, jednak z pohledu změn $v$ charakteru a míre zástavby periferních částí Prahy. Problematika byla řešena komplexně, jak z hlediska množství vod, tak i jejich kvality.
Na základě hlavního cíle projektu byl jako zájmové území vymezen prstenec zahrnující území okrajových částí Prahy podél hranic Prahy se Středočeským krajem. Prstenec (obr. 1) byl vytvořen s využitím hranic hydrologických povodí 4. řádu (prípadně jejich částí), je tedy dobře definován z hlediska odtokových poměrů. Hranice zájmového území jsou stanoveny tak, aby neobsahovaly historická zastavěná území vnitřní Prahy a naopak zahrnovaly území vnější Prahy, kde v posledních desítkách let dochází k největším změnám ve využití krajiny, a s tím souvisejícím změnám odtokových poměrů.

Z hlediska směrů odtoku převažuje na většině zájmového území přítok do Prahy ze Středočeského kraje. Na severovýchodě je ale situace opačná, místní toky odtékají z Prahy do Středočeského kraje (např. Vinořský potok, Mratínský potok), podobně i Kopaninský potok na severozápadě.

Protože jedním z cílů projektu bylo definování přeshraničních vlivů na vodní poměry (hranice Praha - Středočeský kraj), je plocha tzv. prstence vymezena i na relevantní plochy Středočeského kraje. Pưvodní představa byla, že odborné a mapové podklady, které jsou k dispozici pro území Prahy, budou v obdobné formě k dispozici i z území Středočeského kraje. Bohužel se ukázalo, že dostupnost různých podkladů z mimopražských území je mnohem horší, řada informací

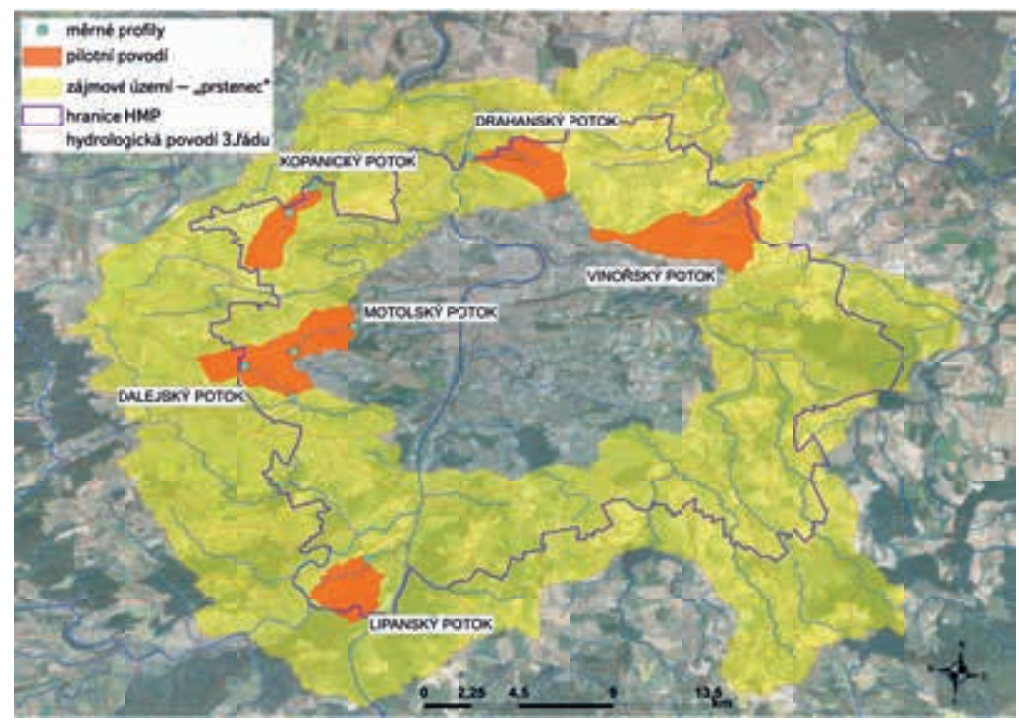

Obr. 1. Vymezení zájmového území projektu, tzv. prstenec vnější Prahy (žlutě). Oranžově jsou zvýrazněna vybraná pilotní povodí. 
vůbec neexistuje (např. podobné inženýrskogeologické mapy, krajský územní plán, mapy zastavěnosti území apod.). Naštěstí se to netýkalo všech podkladů např. topografické mapy z různých dob, mapy využití krajiny CORINE, mapy hydroklimatických dat, vodohospodářské mapy aj. byly dostupné pro celé vymezené území. Přesto však byla hlavní pozornost v průběhu řešení projektu - v souladu se zadáním - soustředěna na území uvnitř hranic hlavního města Prahy.

Na základě analýzy prírodních poměrů, zástavby a charakteru území bylo vybráno celkem šest pilotních povodí, jejichž území bylo zpracováno v detailním pohledu tak, aby výsledky zjištěných změn odtokových poměrů vlivem změn využití území (a také očekávaných dopadů klimatických změn) dobře odrážely různý charakter jednotlivých částí území celého prstence. Pro zjištění postupu zástavby a změny využití území byly analyzovány a vzájemně porovnány mapy z let 1860, 1927, 1953, 2003 a 2015. Níže uvádíme stručnou charakteristiku pilotních území s ukázkou některých map.

\section{KOPANINSKÝ POTOK}

Povodí Kopaninského potoka reprezentuje vodní poměry na severozápadě Prahy ovlivněné denudačními zbytky křídových sedimentů (relativně vyšší základní odtok); povodí je silně poznamenáno existencí letiště. Kopaninský potok pramení $v$ dnešní ploše letiště u ulice K letišti, teče generelně na severovýchod přes obec Přední Kopanina a vlévá se již mimo hranice HMP do Únětického potoka u Kopanského mlýna. Průtok je ovlivněn antropogenními zásahy do odtokových poměrů v oblasti letiště, do potoka jsou svedeny splachové vody z výpadové komunikace Lipská (extrémní průtoky v době př́ivalových srážek), pod obcí Přední Kopanina jsou do potoka zaústěny predčištěné odpadní vody v místní ČOV, dále po proudu je chatová oblast, kde Ize důvodně předpokládat zaústění různě vyčištěných odpadních vod do toku, stejně jako nepodchycené divoké odběry vody pro účely zálivky zahrádek. Na Kopaninském potoce byly instalovány dva vodoměrné profily, jeden monitorující horní část povodí s primárním vlivem letiště a výpadové komunikace, druhý profil byl pak situován pod obcí Přední Kopanina a jeho úkolem bylo sledovat změny vlivem zástavby této obce. Na obou profilech byly sledovány ve stanovených intervalech průtoky a kvalita vody.

Podstatná změna zástavby $v$ tomto území nastala zhruba v 30. a 40. letech 20. století v souvislosti s výstavbou letiště a ve druhé polovině 20. století zastavěnost kontinuálně postupně rostla (rozvoj letiště, komunikací, obecní zástavba). $\checkmark$ posledních 15 letech je situace víceméně ustálená, bez větších změn.
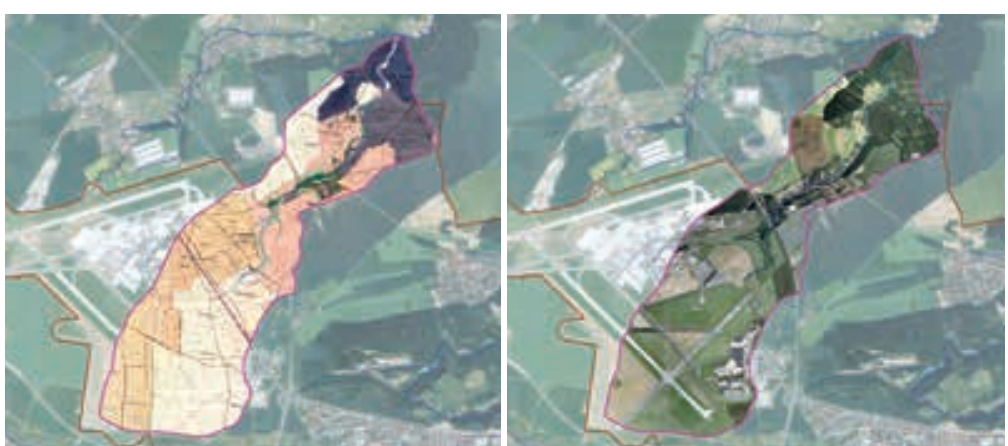

Obr. 2. Kopaninský potok - situace 1860 (vlevo)

Obr. 3. Kopaninský potok - 2003 (vpravo)

\section{MOTOLSKÝ POTOK}

Povodí Motolského potoka reprezentuje poměry západní části Prahy ovlivněné denudačními zbytky kř́lových sedimentů (relativně vyšší základní odtok), povodí je velmi silně antropogenně pozměněno $v$ uplynulých 100 letech mohutnou výstavbou, včetně posledních let (bytová zástavba, rozvoj služeb, obchodní a prưmyslová centra apod.).

Potok pramení na úpatí velmi dobře propustných cenomanských pískovců, ve kterých se dobře akumulují srážkové vody, nedaleko stanice metra Zličín. Údolí pramenné oblasti Motolského potoka doznalo $v$ posledních letech mnoha úprav. Nad severním svahem údolí, kde byly postaveny objekty Tatry Zličín, byly změněny odtokové poměry povrchových vod. Severní svah údolí byl upraven prísypem zeminy. Jižní svah údolí pramenné oblasti Motolského potoka je vymezen skalním útvarem výchozů krídových hornin. Území je zarostlé hájem uměle vysázených topolů, jež mají v současnosti charakter lužního lesa. Podél skalní stěny jsou jezírka s mokřadní vegetací, dotované prameny na rozhraní perucko-rokycanských a bělohorských vrstev.
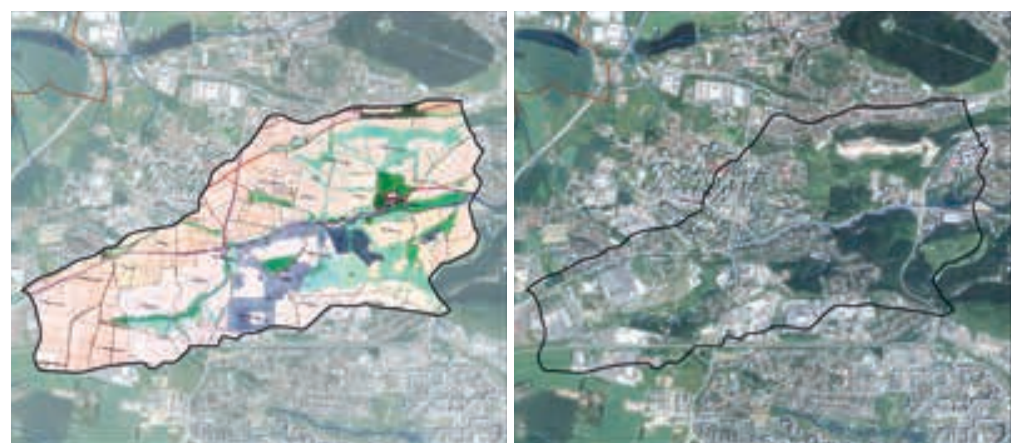

Obr. 4. Motolský potok 1860 (vlevo) Obr. 5. Motolský potok 2015 (vpravo)

Motolský potok se vlévá do Vltavy u Palackého mostu v říčním km 54,42. Z celkové délky 9939 m připadá na dolní, celistvě zakrytý úsek 4251 m a horní, částečně zakrytý úsek 5688 m.

Jako pilotní povodí byla zvolena horní část povodí Motolského potoka, kterou je možné charakterizovat významnými změnami využití území v posledních desetiletích. Jde o část povodí s uzávěrovým profilem v Zahradníčkově ulici pod třemi motolskými rybníky. Dalšími nádržemi na toku jsou Pivovarský a Mlýnský rybník, suchá nádrž Tatra Zličín a několik drobnějších akumulací. Na toku byly zvoleny a zkonstruovány dva vodoměrné profily: jeden na horním toku v pramenní oblasti nad suchou nádrží Tatra Zličín (za účelem monitorování pramenní oblasti silně ovlivněné výstavbou velkoplošných průmyslových, skladových a obchodních objektů) a druhý v místě uzávěrového profilu pod motolskými rybníky (ovlivněný městskou zástavbou klasičtějšího charakteru v oblasti Řep a Motola). Na obou profilech se sledovaly ve stanovených intervalech průtoky a kvalita vody.

Současný stav zástavby nejlépe odráží ortofotomapa z roku 2015, viz obr. 5. Je z ní patrná masivní průmyslová výstavba v horní a jižní části povodí z posledních 30 let, sídlištní zástavba ze 70. let v severní střední části (sídliště Řepy) a ve východní části (areál nemocnice Motol) a doposud převažující volné plochy v dolní části pilotního povodí. Nejstarší dostupná mapa z roku 1860 dokumentuje, že tehdy existovala pouze osada Motol a několik jednotlivých stavení. $\checkmark$ 19. století tak mělo území povodí Motolského potoka jednoznačně prírodně-zemědělský charakter se zanedbatelným antropogenním ovlivněním. 


\section{DALEJSKÝ POTOK}

Povodí Dalejského potoka je charakterizováno významnými zájmy ochrany prírody (Prokopské údolí, geologický charakter utvářen svrchnopaleozoickými vápenci), v horních částech povodí však od 60. let probíhala masivní výstavba (velká sídliště Jihozápadního Města), která pokračuje až dodnes. Navíc významná část horního povodí se nachází mimo hranice Prahy, je zde tedy možné dobře zkoumat přeshraniční vlivy na území metropole.

Dalejský potok pramení v jižní části obce Chráštany, za hranicemi HMP. Na území HMP vtéká za retenční nádrží Třebonice. Potok teče generelně východním směrem do Prokopského údolí (chráněné území př́rody). Do Vltavy se potok vlévá u Zlíchova pod Barrandovským mostem

Mimo hranice Prahy spadají do povodí obce Ořech, Zbuzany a Jinočany. Z městských částí jsou součástí povodí Holyně, Jinonice, Stodůlky, hranice povodí se dotýkají Slivence a Barrandova.

$\checkmark$ povodí je vybudováno několik retenčních nádrží, jež slouží k zachycení velkých vod a k transformaci a zploštění povodňových průtoků (N1 Stodůlky, nádrž Nepomucký a nádrž Asuán na Prokopském potoce, nádrž Třebonice na Dalejském potoce k zachycení vod z dálnice, nádrž Ořech na Ořešském potoce).

Jako pilotní povodí byla zvolena horní část povodí Dalejského potoka do soutoku s Jinočanským potokem v Řeporyjích. Tato část povodí byla vyhodnocena jako území s největšími potenciálními změnami využití území v posledních desítkách let. Na Dalejském potoce byly situovány dva vodoměrné profily pro doplňující hydrometrická měření a vzorkování vod - jeden nad obcí Třebonice v místě vtoku vod na území HMP a jeden na okraji obce Řeporyje, který měl za úkol monitorovat vliv území s pokračující masivní zástavbou (Zličín a Stodůlky). Na obou profilech se sledovaly ve stanovených intervalech průtoky a kvalita vody.
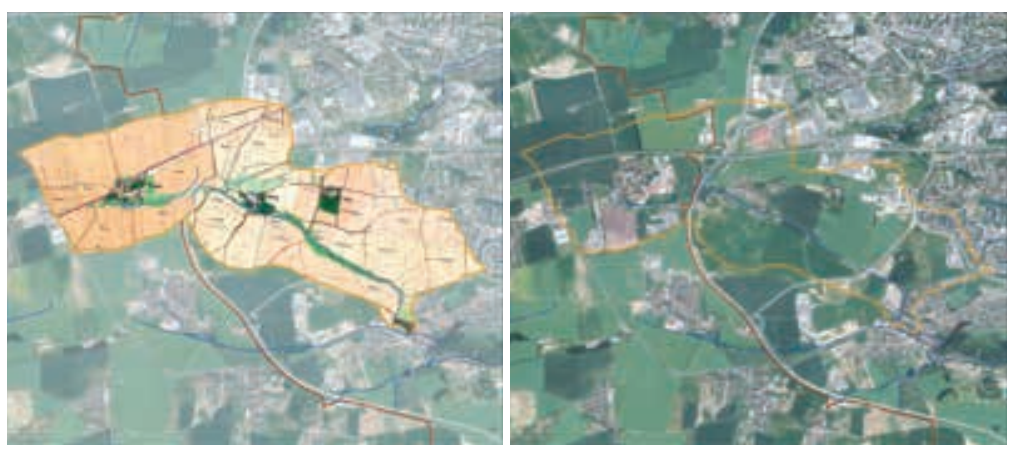

Obr. 6. Dalejský potok 1860 (vlevo)

Obr. 7. Dalejský potok 2015 (vpravo)

Pilotní povodí Dalejského potoka se velmi pomalu a postupně vyvíjelo až do druhé poloviny 20. století a zásadní změny nastaly až v poslední čtvrtině 20. století (stavba sídlišť, výstavba výpadových komunikací, prưmyslová a obchodní zástavba na přelomu století). A neméně intenzivní výstavbu Ize zde očekávat i do blízké budoucnosti. Současnou situaci zobrazuje ortofoto mapa z roku 2015 na obr. 7. Ta nám ukazuje, že vymezená horní část povodí Dalejského potoka zahrnuje mimo Prahu obec Chráštany, v rámci Prahy část Řeporyjí a okrajové části sídliště Stodůlky. Do území také částečně zasahuje průmyslová a obchodní zóna na Zličíně na severu území. Východní a severovýchodní část území obsahuje velké rozvojové plochy určené pro další bytovou a jinou výstavbu, šlo tedy o povodí, jež bylo možné využít pro simulaci očekávaných změn odtokových poměrů v důsledku pokračující masivní zástavby. Na obr. 6 je zobrazena situace území z roku 1860, z mapy jsou vidět jen historická centra osad Chráštany, Třebonice, Chabry a Řeporyje, celé povodí má prírodně-zemědělský charakter.

\section{LIPANSKÝ POTOK}

Reprezentuje odtokové poměry soutokového území Vltavy a Berounky v jižní části Prahy. Geologicky jde o prostředí kvartérních fluviálních štěrkopískových náplavů. Jde o území s relativně malými dopady zástavby na využití krajiny, př́padné změny odtokových poměrů (po eliminaci vlivů velkých toků) tak bude možné interpretovat jako dopady klimatických změn. Významnou aktivitou v posledních letech je velké golfové hřiště, což se může projevit na kvalitě vody. Lipanský potok pramení u ulice Za Hrází západně od Lipenců a protéká směrem na severovýchod podél obce Lipence, skrze velké golfové hřiště a podél Zbraslavi, kde se vlévá do mrtvého ramene Berounky Krňov. Potok protéká mokřinatým územím s vysokou hladinou podzemní vody charakteru lužních lesů, $v$ úseku golfového hřiště je terén upraven. Na toku je několik drobných bezejmenných vodních nádrží. Tok je bez velkého spádu, meandrující, odvodnuující rovinaté území soutokové oblasti VItavy a Berounky. Pilotní území bylo zvoleno z důvodu specifických geologických poměrů odlišných od ostatních pilotních povodí (fluviální štěrkopískové náplavy), dalším specifikem je vliv golfového hřiště na odtokové poměry. Na Lipanském potoce byl instalován jeden vodoměrný profil při ulici K Radotínu, na výtoku potoka z golfového hřiště, aby bylo možné prímo sledovat možný vliv této aktivity na odtokové poměry a kvalitu vody. Na profilu se sledovaly ve stanovených intervalech průtoky a kvalita vody.
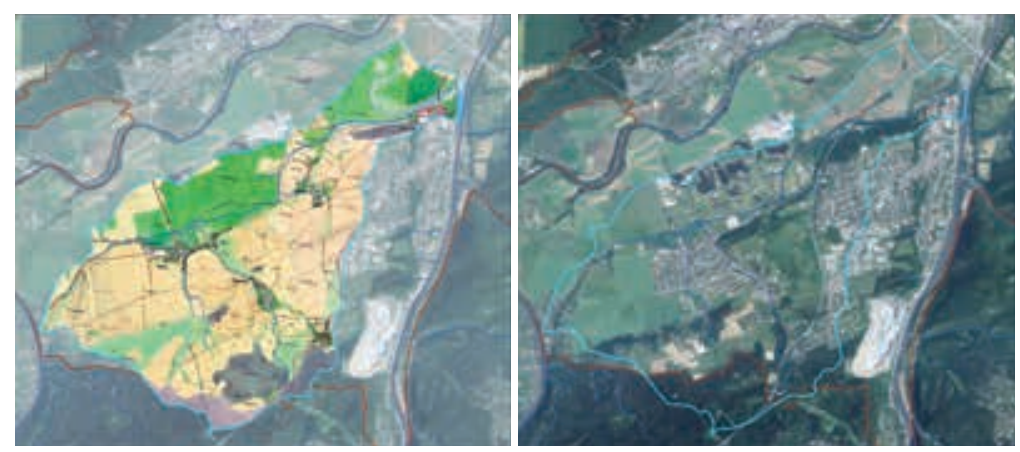

Obr. 8. Lipanský potok 1860 (vlevo)

Obr. 9. Lipanský potok 2015 (vpravo)

Změny zástavby v daném území nejsou významné. Celkově Ize tedy uzavř́t, že pilotní povodí Lipanského potoka se velmi pomalu a postupně vyvíjelo až do druhé poloviny 20. století a určité změny nastaly až v poslední čtvrtině 20. století. Rozvoj výstavby lze zde očekávat do blízké budoucnosti.

\section{DRAHANSKÝ POTOK}

Povodí Drahanského potoka na severu Prahy bylo vybráno s ohledem na doposud zachovaný prevažující volný a prírodní charakter území (pole, lesy, louky) a relativně malou zastavěnost, $v$ níz prevažuje rozvolněná zástavba, hlavně rekreační objekty. Geologicky je území tvořeno břidlicemi, prachovci, křemenci a drobami paleozoického stáří, s denudačními zbytky křídových pískovců.

Drahanský potok pramení v obci Dolní Chabry (cca 305 m n. m.), v požární nádrži v horní části obce, odkud teče generelně k západu a rychle klesá do údolí VItavy. Potok je pravostranným př́tokem Vltavy. Podélný profil toku je poměrně strmý, sklon je 3,3\%. Mělké údolí toku na horním toku v obci Dolní Chabry navazuje v západní části na úzkou a strmou Drahanskou rokli. Ta končí po 1,5 km zaústěním do Vltavy ve 170 m n. m. Na horním toku je několik menších nádrží, včetně retenční nádrže a výpusti předčištěné odpadní vody z místní ČOV. Na Drahanském potoce byl instalován jeden vodoměrný profil, blízko ústí potoka do Vltavy. Na profilu se sledují ve stanovených intervalech průtoky a kvalita vody. 

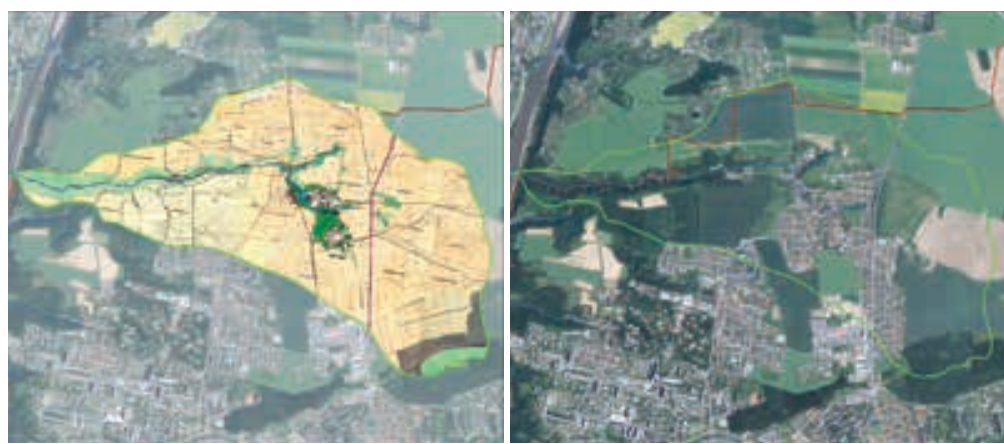

Obr. 10. Drahanský potok 1860 (vlevo)

Obr. 11. Drahanský potok 2015 (vpravo)

Povodí Drahanského potoka můžeme charakterizovat jako území s nejmenšími změnami zástavby za hodnocené období 1860-2015. Považujeme ho tedy za referenční území pro hodnocení projevů klimatické změny, očištěné od urbánních vlivů.

Celkově Ize shrnout, že území povodí Drahanského potoka neprošlo žádnou zásadní změnou za posledních 160 let, jen se pomalu a postupně mírně zvyšovala zastavěnost území, jež ovšem nikdy nepřekročila míru, která by se mohla významněji projevit v omezení infiltrace srážkových vod. Podle dostupných informací ani do blízké budoucnosti není plánována žádná masivní výstavba v daném území.

\section{VINOŘSKÝ POTOK}

Ukazuje odtokové poměry ve východní části Prahy, specifikem je jeho odtok z Prahy do Středočeského kraje (př́tok Labe). Základní odtok je determinován zvětšujícím se množstvím denudačních zbytků křídových pískovců. Povodí je poznamenáno významnou zástavbou v různých historických obdobích (letiště Kbely), včetně mohutného dnešního rozvoje (katastry Kbel, Satalic, Vinoře), zajímavostí je zde i golfové hřiště.

Vinořský potok vyvěrá pramenem Barborka ve Kbelích (výtok z nádrže u Žacléřské ulice) a teče severovýchodním směrem z Kbel do Vinoře, kde po soutoku s Ctěnickým potokem pokračuje již mimo hranice HMP a pokračuje do Brandýsa nad Labem, kde se vlévá do Labe. Jako modelové pilotní povodí byla zvolena horní část potoka do profilu k soutoku s Ctěnickým potokem, který je zároveň profilem na hranici HMP, kde potok opouští Prahu a teče do Středočeského kraje. Pilotní povodí tak zahrnuje část celého povodí Vinořského potoka, jež spadá na území HMP.

Na toku je v pilotním povodí několik menších vodních nádrží (Barborka, Biologický rybník, U Kamenného stolu, rybník u Živanické ulice, Malá Obưrka, Velká Obůrka, Cukrovarský rybník), pod Kbely je do potoka zaústěna předčišstěná odpadní voda z místní ČOV, k jejímuž dočištění slouží ještě retenční nádrž Biologický rybník. V pilotním území byl zvolen jeden vodoměrný profil blízko opuštění potoka území HMP, za výtokem z Cukrovarského rybníku ve Vinoři. Profil byl vhodně zvolen tak, aby odrážel veškeré změny a dopady, které nastanou v části povodí Vinořského potoka, spadající na území HMP. Na profilu se sledovaly ve stanovených intervalech průtoky a kvalita vody.

Specifickým fenoménem daného povodí je existence letiště Kbely, z jehož plochy se voda odvodňuje na severovýchod, právě do Vinořského potoka. Dalším specifikem je velké golfové hřiště mezi Kbely a Vinoří. Současný stav můžeme charakterizovat jako výskyt klasické rozptýlené okrajové městské zástavby $\vee$ částech Kbely, Satalice, Vinoř. V části zástavby Vinoře podél potoka převažují průmyslové a dílenské areály. Ostatní pozemky v povodí Vinořského potoka jsou vesměs zemědělsky využívány, jižně od Vinoře je zalesněné území prírodní rezervace Vinořský park. Nejstarší dostupná situace z roku 1860 ukazuje
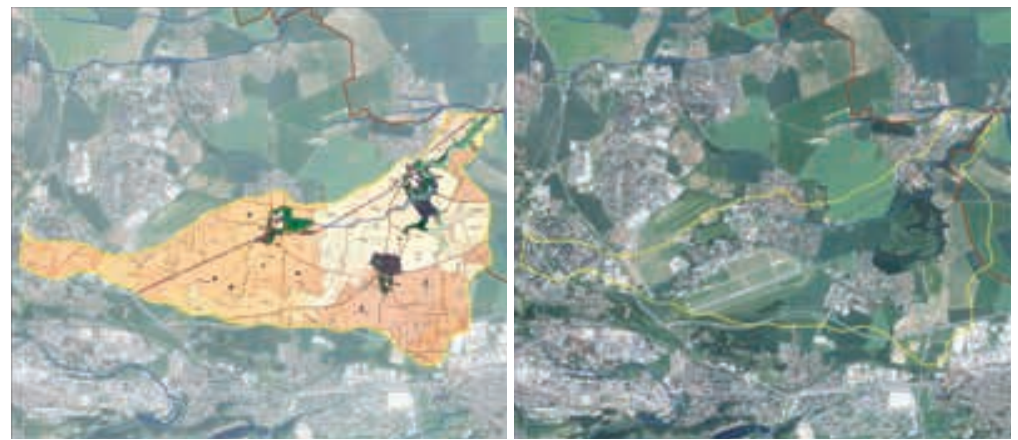

Obr. 12. Vinořský potok 1860 (vlevo)

Obr. 13. Vinořský potok 2015 (vpravo)

jen zárodky osad Kbely a Satalice, jedinou větší obcí v území je Vinoř. Celkově Ize shrnout, že povodí Vinořského potoka prošlo velkou změnou ve 20. a 30 letech 20. století v souvislosti s výstavbou letiště Kbely. To jistě podnítilo i další zástavbu a rozšiřování blízkých obcí, hlavně Kbely. Dalším významným bodem bylo období 60. a 70. let, kdy vznikla blízká velká sídliště Strrížkov a Prosek. V posledním období se postupně rozšiřuje výstavba kolem hlavních center (Kbely, Satalice, Vinoř), nejde však o náhlý, spíše postupný a pomalý vývoj. Do posledních desetiletí se také datuje vznik golfového hřiště mezi Kbely a Vinoří.

Závěrem Ize konstatovat, že vybraná pilotní povodí reprezentují různé přírodní a geologické poměry i různý způsob a dynamiku využití krajiny $\vee$ průběhu let, a byla tak dobrým základem pro následné zobecnění získaných dat. Projekt má několik hlavních výsledků - impaktové články, publikace, výukový modul, mapovou aplikaci a další. Pro zájemce jsou výsledky dostupné na heis. vuv.cz/projekty/praha-adaptacniopatreni. $V$ tomto čísle pak za tímto textem následuji ještě čtyři odborné články, které detailně přibližuji problematiku, jež byla v rámci projektu také řešena.

\section{Autoři}

Ing. Anna Hrabánková

凶anna.hrabankova@vuv.cz

ORCID: 0000-0003-1631-0700

RNDr. Josef Vojtěch Datel, Ph.D.

凶josef.datel@vuv.cz

ORCID: 0000-0003-1451-0135

RNDr. Tomáš Hrdinka, Ph.D.

凶tomas.hrdinka@vuv.cz

ORCID: 0000-0001-5577-794X

DOI: 10.46555/VTEI.2021.01.002 